\title{
Development of a New Phase Change Biogas for Renewable Energy Storage System
}

\author{
Muhammad Kismurtono ${ }^{* *)}$, Satriyo K.Wa, Roni Ma dan Wahyu A. Ra \\ a Technical Implementation Unit for Development of Chemical Engineering Processes, \\ The Indonesian Institute of Sciences, Gunungkidul, 55861. Indonesia.
}

\begin{abstract}
The aims of this study are to decrease the concentration of organic matter are to cooking and generate electricity from biomass. The methods were the preparation of fixed dome reactor, unit of $\mathrm{CO}_{2}$ removal, preparation and fermentation of cow dung, water, chicken manure running and sampling periodically every one hour and data analysis. Therefore, $\mathrm{CO}_{2}$ must be eliminated from the biogas and the corresponding phenomena of mass transfer with chemical reaction of packed column have to be studied. This study assumed steady state and isothermal condition. The system studied consists of packed column (stainless steel 304) $10 \mathrm{~cm}$ in diameter filled with $2 \mathrm{~mm}$ in diameter bead (zeolite) to the height of $80 \mathrm{~cm}$

and storage system of methane.. The gas flow rate was held constant at $\mathrm{F}=800 \mathrm{ml} / \mathrm{s}$, liquid flow rate (L) was $100 \mathrm{ml} / \mathrm{s}$, pressure (P) was varied from: 350 to $700 \mathrm{~mm}$ water column (WC), and the concentration of aqueous $\mathrm{NaOH} 1.5 \mathrm{M}$ inlet absorbent was held constant. The results showed that the percentage of absorbed $\mathrm{CO}_{2}$ can be enhanced by increasing the pressure.

Using column with packing height of $100 \mathrm{~cm}$. gas flow rate of $800 \mathrm{ml} / \mathrm{s}$, using absorbent containing $\mathrm{NaOH} 1.5 \mathrm{M}$ with flow rate: $100 \mathrm{ml} / \mathrm{s}$ and at pressure of $350 \mathrm{~mm}$ water column (WC) and temperature of $30^{\circ} \mathrm{C}$, the percentage recovery of $\mathrm{CO}_{2}$ reacted was $85 \%$. The biogas then will be used to generate electricity.
\end{abstract}

Keywords: Aqueous $\mathrm{NaOH} 1.5 \mathrm{M}$, Biogas purification, $\mathrm{CO}_{2}$ removal, Storage system

\section{Introduction}

At present three different techniques for upgrading of biogas are used commercially in Sweden:

- Absorption with water

- PSA (Pressure Swing Adsorption)

- Adsorption with Selexol TM

Biogas is a clean fuel for internal combustion engine (Angenent, Largus T. et al. 2004). Cooper, John investigated the compressed biogas and natural biogas and their application to diesel fuel.

Biogas was compressed up to $9.8 \times 10^{6}$ for high pressure application.

The benefit of the research is that the research result can be used as pattern to design and analyses packed column for chemical absorption of gas $\mathrm{CO}_{2}$ from biogas, and also for other similar system.

The presence of $\mathrm{CO}_{2}$ in biogas does not give to contribute to the calorific or heating value and are often washed out in purification plant in order to obtain a gas with almost $100 \%$ and dangerous effect on environment

\section{Methodology}

Firstly the biogas introduced at the bottom of the packed column, passing through the aqueous $\mathrm{NaOH} 1.5 \mathrm{M}$ solution, flowing downwards to the solution separator. In this column the $\mathrm{CO}_{2}$ is absorbed and transformed into aqueous $\mathrm{NaOH} \quad \begin{array}{lll}1.5 & \mathrm{M}\end{array}$ solution. Samples of the inlet and outlet biogas were taken during experimental tests using gas sampler. Parameter determined and measured in this experiment were composition of biogas, pressure of biogas, time of burning, $\mathrm{CO} 2$ removal percentage, heat and power. The compositions of these samples were determined by gas 
chromatography. $\mathrm{CO}_{2}$ removal, expressed as a percentage, was calculated by dividing the difference between the inlet and outlet volume compositions by the inlet.

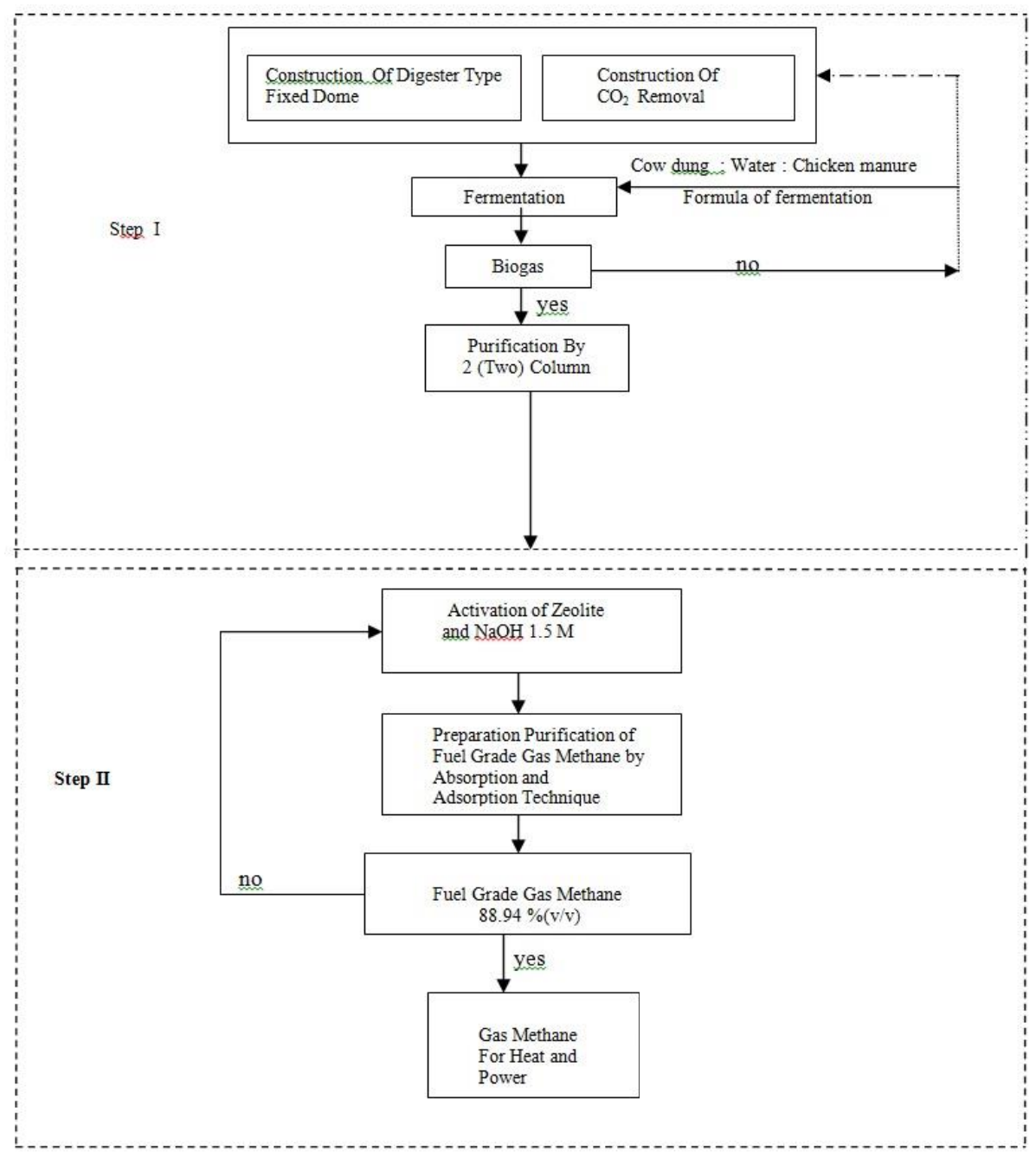

Fig. 1 Research design and methods

Table 1.

Specification of product biogas (before treatment)

\begin{tabular}{ccccc}
\hline No & Component & Percentage & Methods & Composition \\
\hline 1 & $\mathrm{CH}_{4}$ & $\%(\mathrm{v} / \mathrm{v})$ & $\mathrm{GC}$ & 63.20 \\
2 & $\mathrm{CO}$ & $\%(\mathrm{v} / \mathrm{v})$ & $\mathrm{GC}$ & 11.10 \\
3 & $\mathrm{CO}_{2}$ & $\%(\mathrm{v} / \mathrm{v})$ & $\mathrm{GC}$ & 25.19 \\
4 & $\mathrm{H}_{2}$ & $\%(\mathrm{v} / \mathrm{v})$ & $\mathrm{GC}$ & 0.49 \\
5 & $\mathrm{Impurities}$ & $\%(\mathrm{v} / \mathrm{v})$ & $\mathrm{GC}$ & 0.02 \\
\hline
\end{tabular}


Table 2.

Specification of product biogas

\begin{tabular}{cccccc}
\hline No & Component & Percentage & $\begin{array}{c}\text { Composition } \\
(\mathrm{a})^{*}\end{array}$ & $\begin{array}{c}\text { Composition } \\
(\mathrm{b})^{*}\end{array}$ & $\begin{array}{c}\text { Composition } \\
(\mathrm{c})^{*}\end{array}$ \\
\hline 1 & $\mathrm{CH}_{4}$ & $\%(\mathrm{v} / \mathrm{v})$ & $55-65$ & $55-75$ & $40-70$ \\
2 & $\mathrm{CO}$ & $\%(\mathrm{v} / \mathrm{v})$ & - & - & - \\
3 & $\mathrm{CO}_{2}$ & $\%(\mathrm{v} / \mathrm{v})$ & $35-45$ & $25-45$ & $30-60$ \\
4 & $\mathrm{H}_{2}$ & $\%(\mathrm{v} / \mathrm{v})$ & $0-1$ & $1-5$ & $0-1$ \\
5 & $\mathrm{~N}_{2}$ & $\%(\mathrm{v} / \mathrm{v})$ & $0-3$ & $0-0.3$ & - \\
6 & $\mathrm{O}_{2}$ & $\%(\mathrm{v} / \mathrm{v})$ & - & $0.1-0.5$ & - \\
\hline
\end{tabular}

Note.(a) ${ }^{*}$ Arifin dkk.2008; (b) ${ }^{*}$ www.kolumbus.fi; (c) ${ }^{*}$

Muryanto dkk,2006

\section{Results and discussion}

This study we assumed steady state and isothermal condition and the system studied in research comprises a packed column $10 \mathrm{~cm}$ in diameter

filled with $1 \mathrm{~cm}$ ball or $1.6 \mathrm{~mm}$ pellet zeolite to height of $80 \mathrm{~cm}$. This research studied the effect of pressure, concentration of aqueous $\mathrm{NaOH}$ 1.5 M solution in inlet absorbent and temperature on percentage of $\mathrm{CO}_{2}$ absorbed. Liquid flow rate was $40 \mathrm{ml} . \mathrm{s}^{-1}$, pressure was varied 350 and $700 \mathrm{~mm}$ water column (WC). The gas flow rate was held constant at 600 ml. s-1 (Table 3)

Table 3.

Pressure of biogas from digester vsTemperature Maximum from Estimation, ${ }^{\circ} \mathrm{C}$ and Convertion of methan to Co - Generator

\begin{tabular}{|c|c|c|c|c|c|c|}
\hline No & $\begin{array}{l}\text { Pressure of } \\
\text { biogas from } \\
\text { digester, } \\
\text { (mm WC) }\end{array}$ & $\begin{array}{l}\text { Time of } \\
\text { burning, } \\
\text { (hour) }\end{array}$ & $\begin{array}{l}\text { Input gas to } \\
\text { column adsorber } \\
\text { (zeolite) } \\
\%(\mathrm{v} / \mathrm{v})\end{array}$ & $\begin{array}{c}\text { Output gas to } \\
\text { column absorber } \\
\text { (NaOH,1M) } \\
\%(\mathrm{v} / \mathrm{v})^{*}\end{array}$ & $\begin{array}{l}\text { Input gas to } \\
\text { burner or } \\
\text { generator } \\
\%(\mathrm{v} / \mathrm{v})^{*}\end{array}$ & $\begin{array}{l}\text { Temperatur } \\
\text { maximum from } \\
\text { estimation, }{ }^{\circ} \mathrm{C}\end{array}$ \\
\hline 1 & $350 \quad(n)$ & 1 & $54.8900 \quad(\mathrm{n})$ & $71.8700^{*} \quad(\mathrm{n})$ & $88.6200^{*}(\mathrm{n})$ & $1.750^{* * *}$ \\
\hline 2 & $600 \quad(\mathrm{n})$ & 2 & $55.8994^{*} \quad(\mathrm{n})$ & $81.8780^{*}$ (n) & $88.6288^{*}(\mathrm{n})$ & $1.850^{* * *}$ \\
\hline 3 & 350 (n) & 1 & $56.1900^{* *}(\mathrm{n})$ & $82.8700^{* *}(\mathrm{n})$ & $88.4100^{* *}(\mathrm{n})$ & $1.980^{* * *}$ \\
\hline 4 & $700 \quad(\mathrm{n})$ & 2 & $60.1400^{*} \quad(\mathrm{n})$ & $85.8900^{* *}(\mathrm{n})$ & $88.9400^{* *}(\mathrm{n})$ & $2.000^{* * *}$ \\
\hline
\end{tabular}

(n) $3 \mathrm{x}$

8 - Petrolab Services

** - Jaringan Kerjasama Kimia Indonesia Services

*** - Trial and error, law of thermodynamic , $\mathrm{H}=\mathrm{H}_{0} 298+\mathrm{H}_{\text {sensible }}$

With the data above, biogas burners or entrygas generator sets and maximum temperature $(1850-2000){ }^{\circ} \mathrm{C}$, then obtained the following results: In the combustion reaction for pure methane $\mathrm{CH}_{4}+2 \mathrm{O}_{2} \longrightarrow \mathrm{CO}_{2}+2 \mathrm{H}_{2} \mathrm{O}$ (1) If the biogas purification process results in the storage tank $400 \mathrm{~L}$, still entrained $\mathrm{CO} 2$ gas, say with a ratio of $2: 1$, the reaction (1) becomes

$\left(\mathrm{CO}_{2}+2 \mathrm{CH}_{4}\right)+4 \mathrm{O}_{2} \longrightarrow 4 \mathrm{H}_{2} \mathrm{O}+3 \mathrm{CO}_{2}$

So the reaction (1) and (2) the $\mathrm{CO} 2$ gas that is entrained, increasing the volume of exhaust gases or loss of heat energy in the exhaust stack.

In the scrubber column (column absorption and adsorption column), with a burning time of 1 hour, levels of methane gas adsorption column entry (54.89 to 56.19 )\% and the absorption column exit (from 71.87 to 82.87 ) $\%$ and the concentration of methane gas log burning stove (88.41 to 88.68 )\%, there is a decline in the quality of methane gas, this is due to the residual $\mathrm{CO}_{2}$ and gas - inert gas is entrained in the gas methane. When compared to the conditions of the biogas 
digester process pressure (6.0 to 7.0$) 10^{2}$ and 2 hours of burning time, levels of methane gas adsorption column entry (55.89 to $60.14) \%$ and out absorption column (81.87 to 85.89$) \%$ and the concentration of methane gas log burning stove (88.62 to 88.94$) \%$ there is an increase in the quality of methane gas, this is due to the pressure of biogas from the digester is increased from $6.0 \times 10^{2} \mathrm{~cm}$ column of $\mathrm{H}_{2} \mathrm{O}$ to $7.0 \times 10^{2} \mathrm{~cm}$ column of $\mathrm{H}_{2} \mathrm{O}$.

\section{Conclusion}

Results obtained in this research are inferential that:

The percentage of removal $\mathrm{CO}_{2}$ was influenced by absorbent flow rate and pressure of biogas and temperature maximum or heat $2.000{ }^{\circ} \mathrm{C}$ and Power of Generator-Gas Methana 3.000 watt

\section{Acknowledgements.}

The authors wish to acknowledge the donors of Insentif Riset bagi Peneliti dan
Perekayasa Tahun 2009 by DIKTI-LIPI for the support of this study

\section{References}

Angenent, Largus T. et al. 2004, "Production of Bioenergy and Biochemicals from Industrial and Agricultural Wastewater", TRENDS in Biotechnology Vol.22 No.9 September 2004

Anonim, "Biogas", www.electrigaz.com

Anonim, "Biogas", www.wikipedia.org

Anonim, 1998, "Biogas Sumber Energi Alternatif yang Ramah Lingkungan”, Majalah Kampus Genta, Edisi 117, Thn XXXIII, halaman 35-38, Surabaya

Cooper, John, 2001, “Turning Carbon Directly into Electricity", Science and Technology Review, Lawrence Livermore National Laboratory, US Department of Energy

Raven, et.al, 2005, "Biogas plants in Denmark: successes and setbacks", Eindhoven University of Technology, The Netherlands

Setyo I., Yuli, 2005, "Reaktor Biogas Skala Kecil/Menengah (Bagian Pertama)”, ISTECS, Japan, www.beritaiptek.com

United States Patent - 4042332

United States Patent - 5013334

United States Patent - 5174796 